\title{
Reduplicated Nouns in Hausa
}

\author{
PAUL NEWMAN
}

\section{INTRODUCTION}

Hausa is a language that makes extensive use of reduplication in word formation. Reduplication operates productively in constructions such as nominal plurals and adjectival past participles, e.g. gúnóonii 'melons' ( $<$ gúnàa), dàfáffée 'cooked' ( $<$ dáfàa), and is found frozen in synchronically simplex noun and verb roots, e.g. mármáráa 'laterite', bábbàkáa 'to grill'. 'It sometimes is total, e.g. kòoké-kòoké 'complaints', and sometimes partial, e.g. bùuzúuzùu 'dung beetle'. Some reduplicated words preserve the underlying tone of the component parts, e.g. dûddúfàa 'white ibis' ( $<{ }^{*} d \dot{u} f a ̀$ HL + dúfà $\left.\mathrm{HL}\right)$, while some have an independent superseding tonal pattern, e.g. jinà-jinà LLHL 'a red juiced weed' (< jinii $\mathrm{HH}$ 'blood'). In most cases in Hausa the reduplication is evident just looking at the surface form; in others, however, it is more obscure, e.g. jinjirii 'infant' $(<*$ jiri $\dot{i}+$ jiri $)$.

Hausa reduplication as a general phenomenon has been the subject of an important study by Gouffé (1975a), a work characterized by its extensiveness in scope and its carefulness and accuracy in detail. In the present paper, I propose to take a closer look at synchronically frozen reduplicated nouns. More specifically, I shall be limiting myself to an analysis of the some two hundred reduplicated nouns exhibiting the canonical shapes and surface tone patterns illustrated in (1). ${ }^{2}$
a. birbirii
'fruit pigeon'; kàfáffágóo
'a fig tree'
b. bạrbäjèe
'biting ant';
dâddóokàa
'waterbuck'
c. yáryàadii 'a vine'; kùdándàmii
'clay corn bin'
d. shànshàanii 'a centipede'; fùmfünáa
'mildew'

My intention is to account for the presently occurring surface forms in terms of generally regular phonological processes that can be ascribed to Hausa at the time these words were formed. Since these forms are synchronically fixed, it should be understood that the word formation rules described here are historical in nature. (I shall be using the historical present tense, with all the convenience that this English form provides.) 
The paper is thus, in effect, an exercise in internal reconstruction. A number of issues dealt with in the course of the analysis should, nevertheless, have a wider application in Hausa synchronic as well as historical phonology and morphology, e.g. the direction of reduplication, the length of final vowels, and the validity of certain tone rules. As a comprehensive case study, the paper should also contribute to the recently awakened theoretical interest in reduplication as a morphophonological process (Marantz 1982, Odden and Odden 1985).

\section{SEGMENTAL MODIFICATIONS}

The canonical shape of three syllable reduplicated nouns (henceforth RNs) in Hausa is CVCCVCV. ${ }^{3}$ Because of syllable structure constraints, the vowel in the closed syllable in an RN undergoes certain automatic changes. Similarly, because of restrictions on syllable final consonants, the first $\mathrm{C}$ of an abutting pair also undergoes certain changes. These changes are accounted for by the following rules.

1.1. $\mathrm{VV} \rightarrow \mathrm{V} / \ldots \mathrm{C} \$$. A long vowel becomes short in a closed syllable. This is an automatic, synchronically active rule, e.g.

$$
\begin{array}{lll}
\text { bámbàamii } & <{ }^{*} \text { báambàamii } & \text { 'upper part of deleb palm' } \\
\text { kûkkúukìi } & <{ }^{*} k \hat{u} u k k u \dot{u} u k \dot{i i} & \text { 'a gum tree' }
\end{array}
$$

1.2. $e, o \rightarrow a / \ldots C \$$. The mid vowels $/ e /$ and $/ o /$, which would necessarily be short because of the previous rule, shift to $/ a /$ in a closed syllable. ${ }^{4}$ Any palatalization or labialization of the consonant conditioned by the underlying front or back vowel remains after the vowel quality shift, e.g.

$$
\begin{array}{ll}
\text { bâlbéelàa } & <{ }^{*} \text { bêlbéelàa }\left(<{ }^{*} \text { beelbéelàa }\right) \text { 'cattle egret' } \\
\text { dâddóokàa } & <{ }^{*} \text { dôddóokàa }\left(<{ }^{*} \text { dôokdóokàa }\right) \text { 'waterbuck' } \\
\text { kyárkèecíi } & <{ }^{*} \text { kyérkèecii }\left(<{ }^{*} k^{y} \text { éetk }{ }^{y}\right. \text { èetíi) 'wild dog' }
\end{array}
$$

1.3. $\mathrm{T} \rightarrow r / \_$C. If the first consonant of an abutting pair is a coronal

\begin{tabular}{|c|c|c|}
\hline kwârkwátàa & 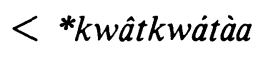 & 'lice' \\
\hline kûrı & $<{ }^{*} k \hat{u} d k \dot{u} d$ & Se \\
\hline & $<$ *yádyàadíi & 'a twiner' \\
\hline$k w a ́$ ? & $<{ }^{*} k w a ́ s k w a ̀ a s a ́ a$ & 'driver ant' \\
\hline
\end{tabular}
obstruent (indicated by $\mathrm{T}$ ) it becomes a rolled $/ r /$, which contrasts with the native Hausa flap $/ r /$. This change follows from a general syllablefinal rule that persists in present-day Hausa. 
When followed by a front vowel, the coronal obstruents $|t|, \mid s /$, and $|z|$ palatalize to $/ c /, / s h /$, and $/ j /$ (or $/ z h /$ in northwestern dialects) respectively. ${ }^{5}$ Since coronals in syllable final position undergo the rhotacization rule rather than the palatalization rule, the identity of underlying coronals in RNs tends to be disguised on the surface, e.g.

$\begin{array}{lll}\text { kyárkèecii } & <{ }^{*} \text { kyátkèetii } & \text { 'wild dog' } \\ \text { kárkáshíi } & <{ }^{*} \text { káskásíi } & \text { 'an herb' } \\ \text { bậrbájèe } & <{ }^{*} \text { bâzbázèe } & \text { 'biting ant' }\end{array}$

\subsection{Gemination}

1.4.1. $\mathrm{P}, \mathrm{K} \rightarrow \mathrm{C}_{\alpha} /-\mathrm{C}_{\alpha}$. A labial or velar, i.e. "grave", obstruent completely assimilates to the following abutting consonant to form a geminate, e.g.

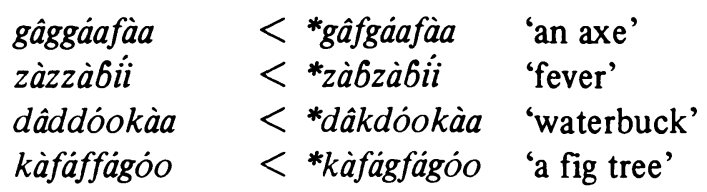

Interestingly, this gemination rule seems to be a property only of reduplicated forms in Hausa rather than being a general phonological rule. ${ }^{6}$ The standard change affecting syllable-final grave obstruents, observed over a half century ago, is a weakening to $/ u /$ (Klingenheben 1927/28, Schuh 1974), ${ }^{7}$ e.g. táushï 'a drum' < *táfshíi, cf. plural táfàashée; sàráunìáa 'queen' < *sàrákniyáa, cf. sárkii 'king'.

\subsection{2. (Optional) $w \rightarrow \mathrm{C}_{\alpha} /-\mathrm{C}_{\alpha}$. When $/ w /$ is the first of an abutting} pair, it either "hardens" and forms a geminate with the following consonant or, like $/ y /$, weakens and forms a diphthong with the preceding vowel (see Newman and Salim 1981). As in the previous rule, the gemination is a characteristic of RNs and is not required by general $\mathrm{P}$ rules. Unlike $/ w /$, the corresponding semivowel $/ y /$ normally does not exhibit gemination, e.g.

$$
\begin{array}{lll}
\text { tsâttséewàa }=\text { tsâutséewàa } & & (<* \text { tsâwtséewàa }) \text { 'a swift' } \\
\text { kàsássáwáa }=\text { kàsáusáwáa } & & (<* \text { *àsáwsáwáa }) \text { 'a long spear' } \\
\text { dáidáyáa } & \neq \text { ??dádááyáa } & (<\text { dáydáyáa }) \text { 'a large millipede' }
\end{array}
$$

1.4.3. $r \rightarrow \mathrm{C}_{\alpha} /-\mathrm{C}_{\alpha}$ [+cor] The flap $/ r /$ commonly appears in syllable final position in RNs. In some cases, an underlying $/ r /$ shows up as an $/ n /$ (see sec. 1.6). Otherwise, when $/ r /$ abuts with a coronal consonant, it assimilates completely to that consonant to form a geminate, e.g. 
1.4.4. Non-gemination of sonorants. In noting the prevalence of gemination in RNs, it is worth pointing out that apart from the case of $/ r /$ just described, which is strictly conditioned, and the case of $/ w /$, which is optional, sonorants and semivowels normally do not undergo gemination. These fixed reduplicated nominals thus do not behave like synchronically productive reduplicated pluractional verbs (the so-called "intensives"), in which underlying sonorants and semivowels often form a geminate with the following abutting consonant, e.g.
a. Kânkánàa kürkútú
'measles'; fürfúráa
'grey hair';
b. Kákkòonée $=$ Kánkòonée kikkíráa = kírkiráa fiffitá $=$ fìrfitá sàssáyàa = sàisáyàa

\begin{tabular}{|c|c|c|c|}
\hline & aulady & large 1 & lшped \\
\hline & & & 'burn \\
\hline kirk & & al & a di \\
\hline $\begin{array}{l}\text { fìrfit } \\
\text { sàisá }\end{array}$ & & & \\
\hline
\end{tabular}

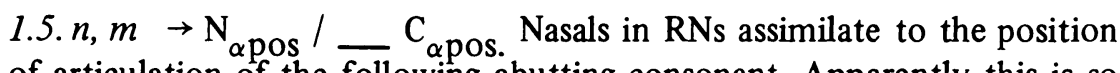
of articulation of the following abutting consonant. Apparently this is so even in the dialects that normally allow unassimilated $/ \mathrm{m} /$ before coronals and velars. Since Hausa does not have $/ \eta /$ as a contrastive phoneme, the velar assimilation is not clearly represented in Hausa orthography nor in Hausa linguistic transcription, e.g.

$\begin{array}{ll}\begin{array}{l}\text { kánkánáa [kánkánáa] } \\ \text { Kàrfámfànáa }\end{array} & <{ }^{*} \text { *ánkánáa 'a melon' } \\ & <{ }^{*} \text { Kàrfánfànáa 'lint at bottom of } \\ \text { tsintsimáa } & <{ }^{*} \text { tsimtsimáa 'a drum' pocket' } \\ \text { gángáamáa [gángáamáa] } & <{ }^{*} \text { gámgáamáa 'steep river bank' }\end{array}$

1.6. (Historical/Sporadic) $\mathrm{C}_{[+ \text {cor }]} \rightarrow n / \rightarrow \$ C$. In some frozen $\mathrm{RNs}$, underlying coronal liquids (and occasionally $/ \mathrm{s} /$ and $/ t s /$ as well) show up as a nasal. (The position of articulation is determined by the just described assimilation rule.) This change is manifested not only in RNs, but also in fixed reduplicated verbs, where the coronal consonant is more often an obstruent. Unlike the other changes that have been discussed, all of which occur to some extent or other in present-day Hausa, this change is manifested only in frozen, lexically fixed forms. The historical nature of this nasalization rule is illustrated more clearly by looking at verbs. Whereas lexically fixed reduplicated verbs, which originally were pluractional forms of simple roots, exhibit nasal replacement for non-nasal coronals, 
see (11b), synchronically generated pluractionals never apply the nasalization rule. The indication "sporadic" on the rule simply means that the nasalization takes place in some words and not in others and that so far the conditioning factor hasn't been identified. ${ }^{8}$ Examples are given in (11) both for RNs and for reduplicated verbs.

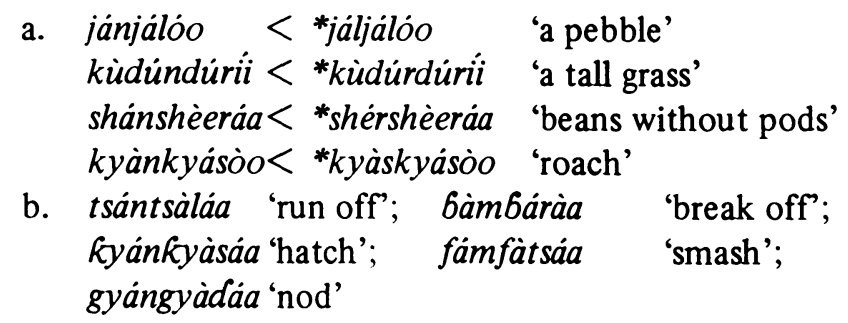

\section{ESSENTIAL NATURE OF THE REDUPLICATIVE PROCESS}

2.1. Forms such as fámfámii 'wood trumpet', jinjirii 'infant', and fàrfèetsii 'a shrub' are usually described as involving reduplication of the initial CVC- of the root (Gouffé 1975a:297). The actual surface forms are then derived simply by applying rules such as those given in sec. 1 above. (The tones of RNs, which will be taken up in sec. 4, are in previous accounts mostly left unexplained.) With forms such as bâlbéelàa "cattle egret' and kwârkwátàa 'lice', on the other hand, the reduplication at the deepest level is assumed to involve copying of the entire root including

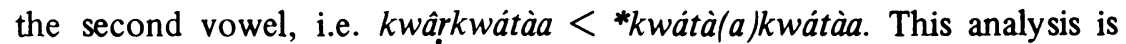
prompted by the presence of the falling tone on the first syllable of the RN. In Hausa, falling tone is nothing but a surface manifestation of high plus low on a single (heavy) syllable. This being the case, RNs with the tone pattern Falling-High-Low ( $=\widehat{\mathrm{HL}}-\mathrm{H}-\mathrm{L})$ can be seen as exhibiting full tone copying along with the segmental reduplication. The vowel that is later dropped is postulated in order to carry the low tone. Given modern nonsegmental approaches to tone (e.g. Goldsmith 1979), it is clear that, theoretically speaking, the postulated vowel is not necessary. One could easily generate kwârkwátàa and similar forms by reduplicating only the initial CVC-segments but the full tone pattern. From a specifically Hausa perspective, however, the analysis involving the postulated vowel is probably correct. First, in less problematic cases, we can see falling tones being created by the deletion of vowels carrying low tones, e.g. min $<$ mini 'to me'; zâi < záayà 'he will'; gyâffáa < *géefàla)fáa 'edges' cf. türàakáa 'te thering posts' (plural of same class).

Second, as we shall see in the following section, assuming an initial CVCV- rather than CVC- enables one to account for the direction of reduplication and for the shape of longer RNs. 
If $\widehat{\mathrm{HL}} \mathrm{HL}$ forms such as bâlbéelàa manifest CVCV-reduplication with subsequent vowel dropping, there seems to be no reason to adopt a different analysis for the RNs with other surface tone patterns. Better is to take a unified approach and postulate the same basic word formation rule for all the RNs. Thus, fámfámii and färfèetsii, for example, should be analyzed as being derived from *fámi(i)fámíi and *fèetsìi)fèetsíi, respectively, in accordance with the general rule for all RNs even though the subsequently deleted vowel is not recoverable from the surface form of these particular words.

2.2. Having settled on the general analysis of the CVC-syllable in RNs as being derived from $\mathrm{CVCV}-$, where the underlined $\underline{\mathrm{V}}$ henceforth indicates the "doomed" (obligatorily deleted) vowel, one can ask what was the length of this postulated vowel. Gouffé (1975b:275-76) specifies a long vowel, which has the advantage of allowing a straightforward

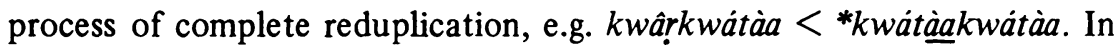
another paper (Gouffe 1975a:297n), however, he leaves the length of the doomed vowel unspecified, perhaps attracted by a short vowel analysis because of the ease with which short vowels in Hausa are deleted as compared with long ones. In fact, from a historical perspective one can have a short, easily deletable doomed vowel and full copying!

A major advance in our understanding of Hausa historical phonology and morphology during the past decade has been the discovery that common nouns (and most other words for that matter) originally ended in a short final vowel (Greenberg 1978, Schuh, 1984 [presented at a 1978 congress]). As explained by Greenberg and Schuh, the long vowels that one now finds on most common nouns are the result of diachronic morphophonological processes related to the suffixation of article-like elements (see also Newman 1979). If the lexically frozen RNs were formed at a time when the final vowels were still short, then one would naturally get the hypothetical forms that make the most sense, i.e. forms that have a short doomed vowel and full reduplication of all the elements (consonants, vowels including vowel length, and tone). Our reconstructed underlying form for fámfámíi would thus be *ámifámi (not ??fámiiffámí nor ??fámifámii) and, similarly, the reconstructed form for kwârkwátàa would be *kwátạkwátà. Subsequently the doomed vowel was dropped and the word final vowel was lengthened (with tonal consequences to be discussed in sec. 4).

2.3. So far we have concluded that the basic form of RNs (limiting ourselves to trisyllabic surface forms) was CVCV-CVCV, where the final vowel of the root as well as that of the copy was short. No mention was made of the quality of the final vowel since this poses no fundamental word formation problem. Nevertheless, it is probably worth pointing out - even though I do not understand the significance of the observation - 
that RNs in Hausa exhibit a much more skewed distribution of final vowels than do simple non-reduplicated nouns. Of the roughly $200 \mathrm{RNs}$ that I have culled from the dictionaries, only two end in $\mid e /$, four in $/ u /$, and fourteen in $/ o /$, with the rest evenly distributed between $/ i /$ and $/ a /$. By contrast, a rough count of an arbitrary list of 200 non-reduplicated nouns in Hausa turned up some twenty words ending in $\mid u /$ and twentyfive in $\mid e /$ and $/ o / .{ }^{9}$ While $/ i /$ and $\mid a /$ are the most common final vowels in non-reduplicated as well as reduplicated nouns, the other vowels appear grossly underrepresented in RNs. It is particularly curious why /e/ should be so rare, especially since it occurs commonly in other reduplicated structures.

\section{DIRECTION OF REDUPLICATION}

Up to this point we have been proceeding as if the reduplication in RNs were to the left, i.e. Copy + Root rather than Root + Copy. At first sight this order seems correct. In dûddúfáa 'white ibis', for example, the syllables /dúfàa/ exhibit the root shape while the CVC syllable /dûd/ has a missing vowel and a changed final consonant. The fact that the first syllable is phonologically deformed is not, however, conclusive evidence regarding its structural status. Starting with an underlying form ${ }^{*} d u f a d u f a$, the deletion rule for the doomed vowel need only specify its position in the RN: it is not important whether the doomed vowel is part of the root or of the copy. Similarly, the change from $|f|$ to $/ d /$ (as with all the other changes described in sec. 1 ) is conditioned by the consonant's surface position as a syllable final abutting consonant without regard to its morphological origin. Since in ${ }^{*}$ dúfádúfà $(\rightarrow$ dûddúfàa $),{ }^{*}$ fámífámi $(\rightarrow$ fámfámíi $)$, *kwátàkwátà ( $\rightarrow$ kwârkwátàa), etc., both appearances of the underlying $\mathrm{CVCV}$ are absolutely identical, one could just as easily reject the usual viewpoint and argue that the order in RNs is Root + Copy, i.e. that the reduplication is to the right. Because the forms themselves throw no light on the issue one way or the other, one has to look elsewhere for evidence in support of the Root + Copy order. First, Hausa is primarily a suffixing rather than a prefixing language and thus reduplication is more likely also to occur to the right (Wilbur 1973, Marantz 1982). Second, most examples of reduplication in Hausa where the direction is evident because the reduplication is partial show reduplication to the right, e.g. ${ }^{10}$

$\begin{array}{ll}\text { (12) dàfáffée } & \text { 'cooked', adjectival past participle of dáfàa } \\ \text { gúnóonìi } & \text { 'melons', plural of gúnàa } \\ \text { dümàamáa } & \text { 'to heat' < dùmíi 'warmth' } \\ \text { bùuzúuzùu } & \text { 'dung beetle' < *buuzu }\end{array}$


Most important, however, is the form of RNs that are more than three syllables in length, e.g.

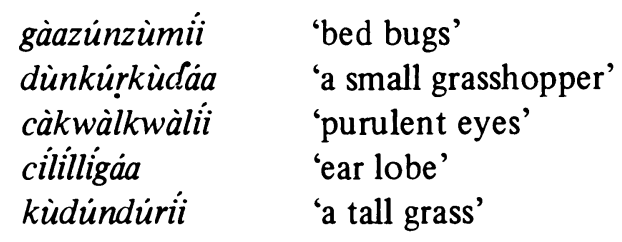

With these longer forms built on three syllable roots, it is clear that the reduplication is to the right rather than to the left, i.e. cililligáa $<$ a root *ciliga + a partial copy *ligá. In the absence of any evidence that would indicate that RNs built on disyllabic roots behave differently from longer forms, we must assume that the direction of reduplication is the same, i.e. fámfámii $<$ a root ${ }^{*}$ fám $i+$ a copy ${ }^{*}$ fámi . Having established a direction of reduplication that is the same in all cases, we can now formulate a single word formation rule for all RNs regardless of their syllable structure.

$\mathrm{RN}=$ Root- $\underline{\mathrm{V}}+$ Copy $2 \mathrm{~S}$ [where $\underline{\mathrm{V}}$ means that the final vowel of the root is "doomed" and Copy $2 S$ means copy the two rightmost syllables of the root including their tones]

In the case of three syllable roots, copying the two rightmost syllables results in an $\mathrm{RN}$ exhibiting partial reduplication. With two syllable roots the resulting output exhibits full reduplication (prior to the deletion of the doomed vowel); but exactly the same rule is involved in both cases, e.g.

$$
\begin{aligned}
& \text { *biri + Copy } 2 S \rightarrow \text { biri-biri } \rightarrow \text { birbirii 'fruit pigeon' } \\
& \text { *bázè + Copy } 2 \mathrm{~S} \rightarrow \text { bázè-bázè } \rightarrow \text { bârbájèe 'biting ant' } \\
& \text { *kàfágó + Copy } 2 \mathrm{~S} \rightarrow \text { kàfágó-fágó } \rightarrow \text { káfáffágóo 'a fig-like tree' } \\
& \text { *kùdàmi }+ \text { Copy } 2 \mathrm{~S} \rightarrow \text { kùdàmí-dàmi } \rightarrow \text { kùdándàmii 'clay corn bin' }
\end{aligned}
$$

In the rule, the overt specification of the doomed vowel $-\underline{V}$ by underlining is a mnemonic that strictly speaking is probably unnecessary. One of the general characteristics of word formation to the right in Hausa is the dropping of the root final vowel, a process that is found in inflection as well as derivation and in verbs as well as nouns, e.g.

$$
\begin{aligned}
& \text { rï̀áa + -únàa 'pl. marker' } \rightarrow \text { rígúnàa 'robes' } \\
& \text { kútúrúu + -tàa 'abstract marker' } \rightarrow \text { kútúrtàa 'leprosy' } \\
& \text { zàabưrà }+-i \text { 'imperative marker' } \rightarrow \text { zàabùri 'spring up!' } \\
& \text { fitá }+ \text {-óo } \quad \text { ventive marker' } \rightarrow \text { fitóo 'come out' } \\
& \text { dàaguràa }+ \text { Copy } 2 \mathrm{~S} \text { 'pluractional' } \rightarrow \text { dàagùrgúràa 'keep gnawing' }
\end{aligned}
$$




\section{TONE:}

Hausa treats the tone of reduplicated forms in two different ways. One mechanism, generally applied in inflectional forms, is to assign a discrete tone pattern to the resultant reduplicated form without regard to the intrinsic tone of the root. The word dúddúgee 'heel', for example, has HHL tone since this is the set pattern for reduplicated words ending in /ee/ designating things that occur in pairs. The other means is to copy the tones of the root along with the segmental units comprising the syllables that are reduplicated, e.g. birbiròo $\widehat{\mathrm{HL}} \mathrm{HL}$ 'adornment' < *biro $\mathrm{HL}+$ biro $\mathrm{HL}$. This is the method employed in the RNs being treated in this paper. Although this type of tonal formation has been recognized with words of certain tonal shapes (particularly $\widehat{\mathrm{HL}} \mathrm{HL}$ words), it has not been recognized in others. This is because the tone copying has been masked on the surface by the operation of certain tone changing rules. Nevertheless, one can show that all of the RNs included in this study are formed by tonal reduplication as well as segmental reduplication. Each of the four tone classes will be described in turn.

4.1. (L/H)HHH. RNs with HHH surface tone are derived from a root $\mathrm{HH}$ plus a copy $\mathrm{HH}$. (When the doomed vowel is dropped, $\mathrm{HH}$ on the resulting closed syllable simplifies to $\mathrm{H}$.) $\mathrm{HHHH}$ nouns come from a root $\mathrm{HHH}+$ a copy $\mathrm{HH}$, while LHHH nouns come from a root $\mathrm{LHH}+$ a copy HH, e.g.

\begin{tabular}{|c|c|}
\hline $\begin{array}{l}\text { mármáráa } \\
\text { gúrgúzúu } \\
\text { fäifái } \\
\text { gililliáa }\end{array}$ & $\begin{array}{l}\text { 'laterite' } \quad<{ }^{*} \text { márá } \mathrm{HH}+\text { márá } \mathrm{HH} \\
\text { 'red sorrel seeds' }<{ }^{*} g \dot{u} z \dot{u} \mathrm{HH}+\text { gúzú } \mathrm{HH} \\
\text { 'round mat'< }<\text { fáyfáyi }<{ }^{*} \text { fáy } \dot{\mathrm{HH}}+\text { fáyi } \mathrm{HH}\end{array}$ \\
\hline $\begin{array}{l}\text { cllilligaa } \\
\text { kàfäffágóo }\end{array}$ & $\begin{array}{l}\text { "earlobe' }<{ }^{*} \text { ciligá } \mathrm{HHH}+\text { ligá } \mathrm{HH} \\
\text { 'a fig tree' }<{ }^{*} \text { káfágó } \mathrm{LHH}+\text { fágó } \mathrm{HH}\end{array}$ \\
\hline
\end{tabular}

4.2. TLHL. RNs with a falling tone on the first syllable are derived from a root $\mathrm{HL}+$ a copy HL. When the doomed vowel is dropped, the low tone of the root is preserved and combines with the high to produce a falling tone, e.g.

$$
\begin{array}{ll}
\text { gâggáafàa } & \text { 'an axe' }<{ }^{*} \text { gáafä } \mathrm{HL}+\text { gáafà } \mathrm{HL} \\
\text { bârbájèe } & \text { 'biting ant' }<{ }^{*} \text { bázè }+ \text { bázè } \mathrm{HL}
\end{array}
$$

I have not come across any examples of four syllable RNs belonging to the $\widehat{H L} H L$ tonal class. There are, however, a few examples of LHHL RNs, which possibly could be tonally simplified forms of the missing words, e.g. 
(19) kwàzázzábòo 'gorge' < *kwàzâzzábòo (?) < LHL + HL dùmúlmúlùu 'cormorant' $<$ *dùmûlmúlùu (?) $<\mathrm{LHL}+\mathrm{HL}$

4.3. (L/H)HLH. RNs with HLH surface tone (in which the tonal reduplication is far from obvious) come from a root $\mathrm{LH}+$ a copy $\mathrm{LH}$. With the apocopation of the doomed vowel, the $\mathrm{H}$ attaches to the $\mathrm{L}$ in the preceding syllable in the same manner that the $\mathrm{L}$ attached to the $\mathrm{H}$ to produce a falling tone in the $\widehat{\mathrm{HL}} \mathrm{HL}$ pattern. Hausa, however, does not have a surface rising tone. As first mentioned by Parsons (1955:385n) and described more fully by Leben (1971), $\widehat{\mathrm{LH}}$ on a single syllable is realized as $\mathrm{H}$, and thus LHLH appears as HLH. This HLH class, which really should be conceptualized as the $\widehat{\mathrm{LH}} \mathrm{LH}$ classes, is thus to LH roots what the $\widehat{\mathrm{HL}} \mathrm{HL}$ class is to HL roots. As is generally the case, longer forms simply display the initial tone ( $\mathrm{L}$ or $\mathrm{H}$ ) of the root in the first syllable of the RN, e.g.

\begin{tabular}{|c|c|c|}
\hline yáryàadiii & 'a twiner' & *yăryàadïi < *yàadị $\mathrm{LH}+$ yàadi $\mathrm{LH}$ \\
\hline jinjirii & 'infant' & $<*_{j} \dot{i}$ injirii $<*$ jiri $\underline{L} \mathrm{LH}+$ jiri $\mathrm{LH}$ \\
\hline kàzúnzùmíi & 'bedbugs' & $<*$ kàzùmzùmïi $<*$ LLH $+\mathrm{LH}$ \\
\hline 'álállàmíi & 'a plant' & $<{ }^{*}$ 'álállàmii $<{ }^{*} \mathrm{HLH}+\mathrm{LH}$ \\
\hline
\end{tabular}

The tonal analysis presented here may also account for the tone of the reduplicated words termed by Parsons (1963:192) "augmentative adjectival nouns (type C)", e.g.

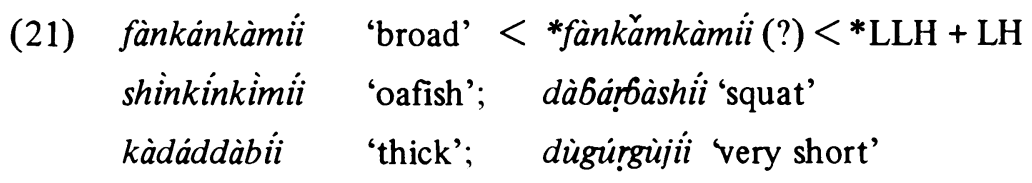

In this case, however, an equally plausible explanation would be that this class of phonaesthetic words has a set LHLH tone pattern associated with it rather than exhibiting a surface tone pattern derived from a combination of the constituent parts.

4.4. (L)LLH. RNs with (L)LLH surface tone are derived from roots with all low tone plus an LL copy. The final high tone that occurs is related to the length of the final vowel. In sec. 2.2 , it was explained that at the historically earlier period when the RNs were formed, Hausa nouns ended in short final vowels. Reduplicating an LL root would naturally produce a form with all low tones and a short final vowel, e.g. * fàla + fálà $\rightarrow{ }^{*}$ fàlfàlà 'a basket'. Subsequently the final vowel of RNs was length- 
ened, as happened to all common nouns, whereupon a tone raising rule came into play. This rule, first described by Leben (1971) and applied in a historical context by Newman (1979), changes a final tonal sequence of LL to LH if and only if the final vowel is long. Taking our hypothetical form *fälfàlà, after final vowel lengthening the word would be *fälfàlàa, which then meeting the condition for the raising rule would change into the now-occurring falfàláa. Although synchronically the raising rule is of problematic status (Newman and Jaggar 1983), historically it seems to have been an automatic, exceptionless P-rule.

fümfünáa 'mildew' $<$ *fümfünàa $<$ *fùmfünà $<*$ fünà $\mathrm{LL}+$ fùnà $\mathrm{LL}$ fàrfèetsii 'a shrub' $<{ }^{*}$ fàrfèetsii $<{ }^{*}$ fàrfèetsi

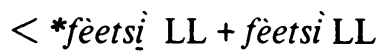

càkwàlkwàlii 'purulence' $<{ }^{*}$ càkwàlkwàlii $<*$ càkwàlkwàli

$$
<\text { càkwàlí LLL + kwàli LL }
$$

There are a couple of interesting examples in Hausa where RNs of this tonal class have undergone apocope and thence further tonal change in accordance with the $\widehat{\mathrm{LH}}$ to $\mathrm{H}$ simplification rule, e.g.

$$
\begin{aligned}
& \text { wàiwái 'a caterpillar' }<\text { *wàiwăi }<\text { wàiwàyaí } \\
& <{ }^{*} \text { wàiwàyaii }<* \text { wáiwày } \dot{i}<\text { *wày }
\end{aligned}
$$

gwàigwái 'an evil spirit' < *gwàigwăi, ultimately $<*^{*}$ gwàyị-gwàyà

kàikái 'chaff' $<$ *kàikǎi ultimately $<*$ *kàyị-kàyi

4.5. In addition to the RNs treated in this paper, there are RNs with two other not uncommon tone patterns that need to be mentioned, namely LHL and LHH, e.g.
a. gùngümàa kyànkyásòo
b. dàddáwáa
'a poisonous plant'
'roach'
'locust bean cake'
'dauber wasp'

The four tone classes of RNs described in sections $4.1-4.4$ correspond to simple roots with $\mathrm{HH}, \mathrm{HL}, \mathrm{LH}$, and LL tone (restricting ourselves to trisyllabic RNs). Since this exhausts the possible tonal shapes for disyllabic roots from which RNs are formed, there has to be some other explanation for the LHL and LHH forms that appear. A full analysis of these tonal classes would take us outside the scope of this paper; nevertheless, 
I would like to offer a couple of suggestions so as not to leave us with the idea that these forms are hopelessly anomalous.

One possibility for the LHL forms is that they represent $\widehat{H L} H L$ RNs that have undergone tonal simplification of the surface falling tone. This is consistent with the existence of tonal doublets cited in the dictionaries such as bàlbéelàa = bâlbéelàa 'cattle egret', and kàrkáaràa = kârḱáaràa 'a thorny acacia'. The other possibility, which applies to both LHL and LHH forms, is that these tonal classes of RNs manifest a set tone pattern belonging to the resultant $\mathrm{RN}$ which is not dependent on the tone of the underlying root. Viewed this way, LHL RNs would reflect a reduplicative pattern *LL.HL (cf. occurring forms such as bidà-bidà 'a dark viper'), while LHH would reflect a $*$ LL.HH pattern.

\section{SUMMARY}

The aim of this paper was to provide a historical account of word formation in Hausa involving synchronically fixed reduplicated nouns. From the analysis of these particular forms, a number of findings emerged that contribute to our understanding of Hausa reduplication in general as well as other areas of Hausa tonology and morphophonology.

(a) Reduplication was to the right rather than to the left for all forms regardless of the number of syllables in the root, i.e. the basic Hausa pattern is Root + Copy, not Copy + Root.

(b) The two rightmost syllables of the root were reduplicated in full, including their two tones.

(b') The reduplication of the tone along with the segmental reduplication is one means of word formation in Hausa. The other means is for the resultant reduplicated form to have a discrete tonal pattern that supersedes the tone of the underlying root and copy.

(c) The closed syllable that appears in the ...CVCCVCV cannonical shape of RNs resulted from the dropping of the root final vowel. When the vowel was lost, its tone nevertheless remained.

(d) Syllable final consonants in reduplicated forms evidenced differences in behavior from the same consonants in non-reduplicated forms. Specifically, RNs manifested a common, but irregular, change of coronal consonants (usually sonorants) to $/ n / \mathrm{a}$ change not attested in non-redplicated forms, while they failed to undergo the change of velar obstruents to $/ u /$, which is the regular, historically well-attested change for non-reduplicated forms.

(e) At the time these now-frozen reduplicated nouns were formed, common nouns all ended in short final vowels. In the original RNs, the final vowel of the root and of the copy would have been short. 
(f) The change of word final L.L to L.H when the final vowel is long operated diachronically as a regular sound change. This rule applied to RNs after the lengthening of the originally short final vowels.

(g) The simplification of $\widehat{\mathrm{LH}}$ on a single syllable to $\mathrm{H}$ also operated as a regular tone rule.

\section{NOTES}

1. The following transcription conventions are employed. Long vowels are indicated by double letters. Acute, grave, and circumflex accent marks indicate high, low, and falling tone, respectively. The accent marks are placed only on the first of a double vowel. The letters $/ c /$ and $/ j /$ represent alveopalatal affricates; $/ t s /$ indicates a coronal ejective, which in the standard Kano dialect is usually a fricative [ $s$ ']. When phonemes represented by digraphs occur doubled, only the first letter of the diagraph is repeated, e.g. $-t_{t s^{-}}=\left[-t s t s_{-}\right],-s h_{-}=[-s h s h-],-g g w_{-}=\left[-g^{w} g^{w} \cdot\right]$, etc. The rolled $/ r /$ is written with a subscript dot to distinguish it from the flap $/ r /$, written without a diacritic. The asterisk * indicates presumed historical forms. Unacceptable forms are marked ??.

2. The examples cited in this paper were taken from the two major Hausa dictionaries: Abraham (1962) and Bargery (1934). Many are obscure words that are unknown to present-day Hausa speakers. Since the paper is concerned with morphophonology rather than lexical semantics, I provide only abbreviated glosses for the Hausa examples. Glosses such as 'a fig tree' or 'a grasshopper' mean that the words in question denote a particular kind of tree or grasshopper, for which one should turn to the major dictionaries for a detailed scientific description.

3. To simplify the presentation, I shall generally describe things in terms of RNs of three syllables, the most common length. The same description is also applicable to longer forms. My use of the cover symbols $\mathrm{C}$ (= consonant) and V (=vowel) is not parallel. Whereas $\mathrm{C}$ represents a single consonant only, $\mathrm{V}$ stands for any vowel whether long or short.

4. The centralling and lowering of $/ e /$ and $/ o /$ in closed syllables is often described as a regular, feature-changing P-rule. Whether the contrast between $/ e /, / o /$ and $/ a /$ is really neutralized in closed syllables, as has been claimed, or whether the consonants remain distinct, at least statistically if not in every particular case, is an unsettled question.

5. Most descriptions of Hausa include $d \rightarrow j$ in this automatic palatalization rule. This is not justified, especially when viewed historically. While $/ d /$ has undergone palatalization in a number of common words, the application of the rule is much less general for $/ d /$ than for the other coronal obstruents. The phoneme $/ d /$ thus stands half-way between $/ \delta /$, which does not palatalize, and $/ t /$, which always does (a few modern loanwords excepted).

6. Marantz (1982) has argued that reduplication is nothing other than affixation in which the affixed material just happens to be phonological identical to the stem. To sustain his extreme position that "there is nothing special about reduplication" (p. 436), he goes to some length to try to explain away the many instances cited in the literature of reduplicated forms behaving differently phonologically from nonreduplicated forms. In my opinion, his rationalization of the contrary evidence is unconvincing. While Marantz may be right that reduplication should be subsumed under the general rubric of affixation, I would argue that reduplication, nevertheless 
qualifies as a distinct process/mechanism with indentifiable phonosemantic and phonological properties (cf. Carrier 1979).

7. The failure of reduplicated forms to obey Klingenheben's law for labials and velars was first brought to my attention a number of years ago in an unpublished paper by Schuh (1968). The special status of reduplicated words in Hausa with regard to phonological rules is further illustrated in Al-Hassan (1983), an interesting thesis concerned primarily with intensive (i.e. "pluractional") verbs.

8. If it is true that the consonant affected by the rule must be a coronal, then the word yânyáawàa 'fennec', presumed to be derived from *yáawà-yáawà, must have some explanation other than the direct replacement of $/ w /$ by $/ n /$.

9. The count of non-reduplicated words was based on the first 200 items (excluding English loanwords and active verbal nouns) in a mimeographed alphabetical list of disyllabic nouns having distinct plural forms prepared by F.W. Parsons.

10. Synchronically, pluractional verbs in Hausa are generally formed by reduplication to the left, e.g. gággáskàtáa 'reverify' < gáskàtáa 'verify'. Historically, however, the reduplication was almost certainly to the right since this is the formation evidenced in all the lexically frozen pluractional verbs, e.g. fátáttàkáa 'lacerate, rout' $<$ *fataka, gútsúntsùnáa 'break into fragments' < *gutsuna.

APPENDIX 1: Reduplicated Nouns Organized According to Tone Class (Note: in the appendices, high tone is left unmarked.)

(a) Tone class $(\mathrm{L} / \mathrm{H}) \mathrm{HHH}$

di-/trisyllabic:

bambamii 1. climbing plant;2. sunbird barbaraa copulation of animals barbaroo any cloth of mixed colors bilbiloo 1 . swallow; 2 . butterfly birbirii Bruce's fruit pigeon baibaavaa poor cornstalks used for fodder daidayaa large millipede diddigii investigation, probing faifai small round mat famfamaa cranium famfamii wooden trumpet blown for chief famfaroo bare land furfuraa gray hair gaggaafaa eagle gaggaawaa/gaugaawaa haste gangaamaa/gangaamii steep river bank gangamii drumming gargadaa 1 . bad wash-out on road; 2 . mange of goat or sheep

gargarii red-clay soil gargazaa cichlid perch gurgurii short person gurguzuu a group of one type gwangwalaa midrib of raffia palm branch gwangwalee flower of custard apple tree gwangwan(ii) small metal basin gwangwaanii meddlesomeness gwargwaadaa male lizard gyangyamaa wall around glass shelter janjaloo a pebble jinjimii sacred white ibis kankamoo useless guinea corn kankanaa type of watermelon karkashii an herb kukkubaa cracked cooking pot kunkumii type of drum kurkuraa type of guinea corn kurkutu small drum $k$ walkwalii type of cap $k$ wankwamaa cave kwarkwadaa top of horse's head kwarkwaroo spindle $k$ warkwasaa small hammer kyakkkyabii trembling, shivering karkarii eagerness

Kanfaumaa skimpy, sleeveless gown kwakkwafii inquiring, probing kwankoolii summit 
kwankoonii dark residual groundnut oil malmalaa long cake of tuwoo

mormaraa laterite

marmarii desire, longing

marmaroo a natural spring

sansamii a small tree

shasshakaa balls of rice or millet served 1 in oil

shisshigii meddlesomeness

taitai small round mat

tantamaa doubt

tantaamii raised platform

tantaanii membrane

tuntumii sacred white ibis

tsantsanii fastidiousness, aversion

tsattsafaa thin weat cakes with honey

tsintsimaa open-ended drum of hunters

vanyanii speech impediment

warwaroo thin metal bracelet

zanzanaa small pock marks

quadrisyllabic:

'àdindimaa a grasshopper

'ararrafii frankincense tree

'ararrafoo type of locust

'awarwaroo a convolvulus

càakulkuilii tickling armpits of children

cililligaa 1. ear lobe; 2 . earring

damarmaraa spiteful false accusation

käfaffagii wide-mouthed (vessel)

káfaffagoo fig-like tree

kaiiniirii type of palm tree

kàsassafiaa ill-effects of wrongful acts

kàsassawaa type of long spear

kàatuntunaa amber necklace stone

kijiijiirii/kijinjirii type of palm tree

kudduddufii borrow-pit

küdudduraa/küdunduraa kitchen knife

kidundurii type of tall grass

kururrumii broken necked (pot)

kürurrawaa bell

Kuirurrubii shallow water hole

kwalkorlen'aa summit

maciaidaya miilipede

màafundumii 1. blind-inan's buff: 2. small

duck-like bird

màjaịawaa/màjaujawaa slingshot

makwakkwafii woodpecker

ma!allafii martingale

màshassharaa fever, smallpox

shiminnikii sloth, dilatoriness (b) Tone class $\widehat{\mathrm{HL}} \mathrm{HL}$

bâlbeelàa cattle egret

bâlbeetàa a scalpel

bârbajèe biting ant

bibbigàa parakeet

birbiròo adornment

dâddaagàa iron band at end of spear shaft

dâddookàa western waterbuck

dândaanàa an herb

dûddufàa sacred white ibis

dûddurùu small stream

dâddoyà fragrant herb

gâggaafàa type of axe

gwângwaamàa canna plant

kâkkaawàa loud laughter of men

kûkkuukii gum tree

kûrkudùu sandhopper

$k$ wârkwaasàa driver ant

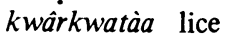

kânkanàa measles

Kârkaadòo Preuss's cliff swallow

Kârkaaràa thorny acacia

Kwâaifwaayàa prolapse

Kwârkwaràa concubine

kyâkKeegàa lame excuses

Kyârkyaarii starling

lâulaawàa bicycle

shâsshaawàa/shâushaawàa tribal marks

tsâttseewàa/tsâutseewàa 1. any swift;

2. Senegal swallow

wârwaajii white oryx

'yấ 'y 'yaawàa poor cornstalks cut for

fodder

(c) Tone class (L/H)HLH

trisyllabic:

bambàamii upper part of deleb palm

dandòonaa a blight affecting millet

daddòorii a creeper

fyarfyaacii sore on foot from travelling

janjàmii horse-cropper

janjànii refractory peison

jinjirii baby

kwarkwàasaa driver ant

kyarkèecii a wild hunting dog

shainshèeraa unhusked groundnuts or rice

tattàashii peppers 
tsattsàagii a shrub yaryàadii a climbing vine

zanzàlaa empty-handed

quadrisyllabic:

'alallàfaa martingale

'alallamii plant used as substitute for henna 'àlgungùmii mischief maker

'alillibaa a tree

bùduddùgii type of edible frog

bùlullukKaii greater intestine

bùttuntùnaa smut fungus

càkarkàrii 1 . well pulley; 2 . part of loom

digirgirii handle of scribes' ink bottle

dùnkurkùdaa small, black grasshopper

gàazunzùmii bed bugs

kùdandàmii clay corn bin

kwàrarràbii kind of snake

Kàrfamfànaa lint at bottom of pocket

kàasunsùmii wet autumn mist

Kärgungùmaa beetle

Kairurrùcii striving hard

Kyàafirfitaa sandfly

magargàraa self-sown guinea corn

málalláfii martingale

sàwarwàrii carelessness, misfortune

shikinkimii loony, dolt

tàfarfàraa entrance hut

tàkarkàrii pack ox

tàakunkùmii muzzle

tàakurkùdaa grasshopper

tàmalmàlaa/tàmammànaa smegma affecting boy's penis

yàabirbiraa type of bat

(d) Tone class (L)LLH

bàmbàmii raising the voice in anger

bùbbùucii a grass

bùrbùrwaa mild scabies

6ärbashii crumbs càbàlbàlii mud

càkwàlkwàlii purulent (of eyes)

dàddòofaa flattery, syncophancy

dàndàree food made from baobab fruit

fàrfèetsii a medicinal shrub

fàlfàlaa a basket

fümfum lampblack

fümfünaa/hùnhùnaa mildew

gàngàmoo turmeric

gàrgàraa rashness

gwàigwai/gwàigwàyaii evil spirit

hàràrràmii uproar

'in 'iinaa stuttering

jàjjòogaa cantering

jüujùwaa clump of date palms

kàkkàawaa selling meat on credit

$k$ wànkwàmii raising voice in anger

kwànkwànii poison shrub

kwàrkwàshii dandruff

Käikai/Kàikàyii 1. chaff; 2. itching

Känkauunii muttering in complaint

Kwàlkwàlee struggling for basic supplies

kyàlkyàlii glittering

màrmàtsii pinching playmate's wrist

mürmùshii smile

ràiràyii fine sand

sànsàamii foliage

sàssàgoo small saw

shànshàanii flat centipede

shàsshèekaa gasping

tittishii 1. happiness; 2 . flouriness of cooked tubers

tsäntsàanii fastidiousness

tsàttsàfii toy flute from onion stem

tsäutsàyii accident with physical or monetary loss

wàiwai/wàiwàyii caterpillar

wàlwàlaa cheerful disposition

yànyàmii crawling feeling of insects

on body

zànzòomaa badgering a person

zàzzàbii fever

zùzzùubaa cornstalks fitted in roof beam

APPENDIX 2: Coronal to / $n$ / Change in Reduplicated Words

(a) Nouns

bàmbaroo 'puffiness'

dàndàree 'a food from baobab fruit'

dàndarii 'coccyx' famfaroo 'bare land'

gwangwalaa 'midrib of raphiapalm branch

gwangwalee 'flower of custard apple tree' 
janjalco 'a pebble'

jinjirii 'infant'

kijinjirii 'a palm tree'

külunduraa 'a kitchen knife'

kiudundurii 'a tall grass'

kimkuruu 'tortoise'

kwankwasoo 'lumbar region'

klankiasòo 'roach'

kànkaràa 'flint, hail'

Gimfanıriu 'one cowrie out of a hundred'

kwankoolii 'summit'

sansarii 'type of cane'

shanshicraa 'unhusked kernels'

zanzàlaa 'empty-handed'

zànzaroo 'dauber wasp' (b) Verbs

Gàmbaràa 'tear off'
dàndatsàa 'mock'
dändasàa 'break up'
famfäree 'shed milk teeth'
famfätsaa 'smash'
gangàraa 'descend, roll down'
güngutsàa 'defame'
gyangyàdaa 'nod from drowsiness'
gyangy'àree 'fall unconscious'
kankàraa 'scrape lightly'
kwànkwadàa 'gulp down'
kwankwàtsaa 'shatter'
Kankäraa 'make thing well'
kwankwàsaa 'tap with knuckles'
kyankvàsaa 'hatch'
tsantsälua 'run off'

\section{REFERENCES}

Abraham, R.C. 1962. Dictionary of the Hausa Language. London: University of London Press.

Al-Hassan, Bello S.Y. 1983. Intensivization: A Study of the Phonology and Semantics of a Category of Hausa Reduplicants. M.A. thesis, Ahmadu Bello University.

Bargery, G.P. 1934. A Hausa-English Dictionary. London: Oxford University Press. Carrier, Jill L. 1979. The Interaction of Morphological and Phonological Rules in Tagalog. Ph.D. dissertation, MIT.

Goldsmith, John A. 1979. Autosegmental Phonology. New York: Garland.

Gouffé, Claude. 1975a. Redoublement et réduplication en haoussa: formes et fonctions. Bull. de la Société de Linguistique de Paris 70(1): 291-319.

_. 1975b. Noms vernaculaires d'animaux et ethnozoologie: le point de vue du linguiste (lexicologie haoussa). In L'homme et l'animal, $1^{\text {er }}$ Colloque d'Eth nozoologie, pp. 273-82. Paris.

Greenberg, Joseph H. 1978. How does a language acquire gender markers? In Universals of Human Language 3: Word Structure, ed. by J.H. Greenberg, pp. 47-82. Stanford: Stanford University Press.

Klingenheben, A. 1927/28. Die Silbenauslautgesetze des Hausa. Zeitschrift für Eingeborenen-Sprachen 18:272-97.

Leben. William R. 1971. The morphophonemics of tone in Hausa. In Papers in African Linguistics, ed. by C.W. Kim and H. Stahlke, pp. 201-218. Edmonton: Linguistic Research, Inc.

Marantz. Alec. 1982. Re reduplication. Linguistic Inquiry 13:435-82.

Newman, Paul. 1979. Explaining Hausa feminines. Studies in African Linguistics $10: 197-226$

Newman. Paul, and Philip J. Jaggar. 1983. Synchronic violations of "low tone raising" in Hausa. Paper presented at the 14th Conference on African Linguistics, University of W'isconsin (Madison).

Ncwman, Paui, and Bello A. Salim. 1981. Hausa diphthongs. Lingua 55:101-121.

Odden. David, and Mary Odden. 1985. Ordered reduplication in Kihehe. Linguistic Inquiry 16:497-503. 
Parsons, F.W. 1955. Abstract nouns of sensory quality and their derivatives in Hausa. In Afrikanistische Studien, ed. by J. Lukas, pp. 373-404. Berlin.

- 1963. The operation of gender in Hausa: stabilizer, dependent nominals and qualifiers. African Language Studies 4:166-207.

Schuh, Russell G. 1968. Some problems in Hausa consonant clusters: a critical study of Klingenheben's law. Unpublished ms., UCLA.

- 1974. Sound change as rule simplification? A study of consonant weakeming in Kanakuru and Hausa. In Third Annual Conference on African Linguistics, ed. by Erhard Voeltz, pp. 95-101. Bloomington: Indiana University.

- 1984. West Chadic vowel correspondences. In Current Progress in Afro-Asicatic Linguistics, ed. by James Bynon, pp. 167-223. (Current Issues in Linguistic Theory, 28). Amsterdam: Benjamins.

Wilbur, Ronnie B. 1973. The Phonology of Reduplication. Bloomington: Indiana University Linguistics Club.

Department of Linguistics

Indiana University 